\title{
Evaluating zinc isotope fractionation under sulfate reducing conditions using a flow-through cell and in situ XAS analysis
}

\author{
Julia H. Jamieson-Hanes ${ }^{\text {a }}$, Heather K. Shrimpton ${ }^{\text {a }}$, Harish Veeramani ${ }^{\mathrm{ab}}$, Carol J. Ptacek ${ }^{\mathrm{a}}$, \\ Antonio Lanzirotti ${ }^{\mathrm{c}}$, Matthew Newville ${ }^{\mathfrak{c}}$, David W. Blowes ${ }^{\mathrm{a}, *}$ \\ ${ }^{a}$ Department of Earth and Environmental Sciences, University of Waterloo, Waterloo, ON, N2L \\ 3G1, Canada \\ ${ }^{\mathrm{b}}$ Present address: School of Engineering, University of Glasgow, Glasgow, G12 8QQ, United \\ Kingdom \\ ${ }^{\mathrm{c}}$ Center for Advanced Radiation Sources, University of Chicago, Chicago, IL 60637, USA \\ *Corresponding Author \\ E-mail address: blowes@uwaterloo.ca
}

\begin{abstract}
A flow-through cell experiment was conducted to evaluate $\mathrm{Zn}$ isotope fractionation during $\mathrm{ZnS}$ precipitation under microbially-mediated sulfate-reducing conditions. Synthetic groundwater containing $0.90 \mathrm{mM} \mathrm{Zn}$ was pumped through a cell containing creek sediment that was biostimulated to promote sulfate reducing conditions. Real-time, in situ X-ray absorption spectroscopy (XAS) was applied at the Zn K-edge to collect spectra via a Kapton window in the front of the cell over the course of the experiment. Aqueous effluent samples were collected and analysed to determine concentrations of anions and cations, and $\mathrm{Zn}$ isotope ratios. The flow rate was increased step-wise during the experiment to modify the residence time and produce changes in the extent of sulfate reduction, which in turn controlled the extent of $\mathrm{ZnS}$ precipitation. Greater enrichment in the heavier isotope in the aqueous phase relative to the input solution was associated with more extensive $\mathrm{Zn}$ removal. A Rayleigh curve was fit to the isotope data, where $\varepsilon=-0.27 \pm 0.06 \%(2 \sigma)$. Evaluation of $\mathrm{Zn}$ isotope fractionation under controlled flow conditions is critical to improve the efficacy of this powerful analytical technique when applied to natural systems or remediation projects in the field.
\end{abstract}




\section{Introduction}

Zinc $(\mathrm{Zn})$ is an essential micronutrient that is involved in numerous biogeochemical processes in the environment (Labrenz and Druschel, 2011). However, Zn can be toxic when concentrations become elevated; for example, amphipods have been shown to be impacted by $\mathrm{Zn}$ concentrations in the range of $200 \mu \mathrm{g} \mathrm{L}^{-1}$ (Besser and Leib, 2007). Anthropogenic activities such as mining can result in increased $\mathrm{Zn}$ concentrations in soil, surface water, and groundwater (Al et al., 1994; Moncur et al., 2005). Release of $\mathrm{Zn}$ from mine wastes due to sulfide mineral oxidation is frequently accompanied by elevated concentrations of sulfate $\left(\mathrm{SO}_{4}{ }^{-2}\right)$ and either acidic or neutral pH conditions (Lindsay et al., 2009; Blowes et al., 2014). Passive treatment of Zn via $\mathrm{ZnS}$ precipitation under microbially-mediated sulfate reducing conditions has been shown to be a viable remediation technique (Waybrant et al., 1998; Blowes et al., 2000; Waybrant et al., 2002).

Under anaerobic conditions, sulfate-reducing bacteria (SRB) participate in the reduction of sulfate to sulfide, coupled with the oxidation of organic carbon (Blowes et al., 2000):

$$
2 \mathrm{CH}_{2} \mathrm{O}_{(s)}+\mathrm{SO}_{4(a q)}^{2-}+2 \mathrm{H}_{(a q)}^{+} \rightarrow \mathrm{H}_{2} \mathrm{~S}_{(a q)}+2 \mathrm{CO}_{2(a q)}+2 \mathrm{H}_{2} \mathrm{O}_{(l)}
$$

The presence of aqueous hydrogen sulfide can lead to the precipitation of $\mathrm{Zn}$-sulfide, effectively removing it from solution:

$$
\mathrm{Zn}_{(a q)}^{2+}+\mathrm{H}_{2} S_{(a q)} \rightarrow \mathrm{ZnS}_{(s)}+2 \mathrm{H}_{(a q)}^{+}
$$

Provided anaerobic conditions are maintained, this highly insoluble form of Zn (Lawrence and McCarty, 1965) can be a long-term sink.

Zinc has five stable isotopes, ${ }^{64} \mathrm{Zn},{ }^{66} \mathrm{Zn},{ }^{67} \mathrm{Zn},{ }^{68} \mathrm{Zn}$, and ${ }^{70} \mathrm{Zn}$, with natural abundances of $49.17 \%, 27.73 \%, 4.04 \%, 18.45 \%$, and $0.61 \%$ (Meija et al., 2016). First pioneered by Maréchal et al. (1999), Zn isotope ratio analysis has emerged as a powerful technique for 
tracking geochemical processes in the environment and identifying sources of both natural and anthropogenic Zn contamination (e.g., Pokrovsky et al., 2005; Borrok et al., 2009; Aranda et al., 2012). To apply $\mathrm{Zn}$ isotope ratio measurements as a tool to better understand complex natural systems, it is critical to characterize the $\mathrm{Zn}$ isotope behaviour that is attributed to each reaction mechanism. Controlled laboratory batch experiments provide insight into $\mathrm{Zn}$ isotope behaviour in pure systems. For example, Pokrovsky et al. (2005) observed very little fractionation during sorption of $\mathrm{Zn}$ to Fe and Mn oxides, reporting average shifts of up to $0.2 \%$ for ${ }^{66} \mathrm{Zn} /{ }^{64} \mathrm{Zn}$; similar ranges of fractionation were reported for $\mathrm{Zn}$ sorption to ferrihydrite (Veeramani et al., 2015). Juillot et al. (2008) reported $\Delta^{6 / 64} \mathrm{Zn}_{\text {sorbed-aqueous }}$ values of $+0.29 \%$ for $\mathrm{Zn}$ sorption on goethite and $+0.53 \%$ on 2-Lines ferrihydrite, whereas Balistrieri et al. (2008) reported $\Delta^{66 / 64} \mathrm{Zn}_{\text {soln-solid }}$ values of $-0.52 \%$ for $\mathrm{Zn}$ adsorption onto amorphous ferric oxyhydroxide. In contrast, values of $\Delta^{66 / 64} \mathrm{Zn}_{\text {adsorbed-dissolved }}$ up to $+2.7 \%$ were observed for $\mathrm{Zn}$ adsorbed to birnessite at high ionic strength (Bryan et al., 2015). Relatively large shifts in Zn isotope composition occur during mineral precipitation reactions. Aqueous $\mathrm{Zn}$ is enriched in the heavier isotope during $\mathrm{ZnS}$ precipitation, whereas during $\mathrm{Zn}$-carbonate and $\mathrm{Zn}$-phosphate formation, aqueous $\mathrm{Zn}$ is depleted in the heavier isotope (Veeramani et al., 2015). Magnitudes of $\mathrm{Zn}$ isotope fractionation determined experimentally are in good agreement with those predicted by computational techniques (Black et al., 2011; Fujii et al., 2011; Fujii et al., 2014). Building on these pure-system batch experiments, laboratory experiments incorporating greater complexity (e.g., simulated groundwater, natural reactive materials) and saturated flow will provide an opportunity to evaluate $\mathrm{Zn}$ isotope ratio measurements as a tool under conditions that more closely represent real-world systems. 
The objective of this study was to identify the mechanism of aqueous $\mathrm{Zn}$ removal under microbially-mediated sulfate reducing conditions, and to evaluate the concomitant $\mathrm{Zn}$ isotope behaviour during Zn removal by natural sediment under saturated flow conditions. Following the experimental design pioneered by Jamieson-Hanes et al. (2014), a flow-through cell experiment was conducted to acquire real-time, in situ speciation of the $\mathrm{Zn}$ removed from solution, and to simultaneously collect aqueous $\mathrm{Zn}$ for isotopic analysis. Solid-phase $\mathrm{Zn}$ and sulfur (S) X-ray absorption spectroscopy (XAS) was combined with aqueous $\mathrm{pH}$ and redox measurements, cation and anion concentrations, $\mathrm{Zn}$ isotopic analyses, and microbiological characterization to provide a more complete understanding of the biogeochemical processes during $\mathrm{Zn}$ removal by natural sediment under sulfate-reducing conditions. Assessment of $\mathrm{Zn}$ isotope fractionation in this system is critical for the application of isotope analyses to understand $\mathrm{Zn}$ cycling in natural systems, which will also aid remediation endeavours.

\section{Materials and Methods}

\subsection{Cell design}

A flow-through cell (FTC) was fabricated using high-density polyethylene (HDPE) following a similar design to that used in Jamieson-Hanes et al. (2014). The dimensions of this cell were greater than that used in a previous study, with the open-faced indentation measuring $3.8 \times 7.6 \times$ $1.3 \mathrm{~cm}\left(37.5 \mathrm{~mL}\right.$ internal volume, $28.9 \mathrm{~cm}^{2}$ face area; Figure 1). A HDPE frame was affixed to the face of the cell to hold in place an $80 \mu \mathrm{m}$-thick sheet of Kapton® film allowing X-ray penetration; a rubber O-ring provided a fluid-tight seal. The outer dimensions of the cell were $17.8 \times 14.0 \times 6.4 \mathrm{~cm}$. Synthetic groundwater was passed through the cell via $2 \mathrm{~mm}$ ports installed at the bottom and top of the cell. 


\subsection{Experimental setup}

Natural sediment was collected from the anaerobic zone of Columbia Lake in Waterloo, Ontario, Canada $\left(43^{\circ} 28^{\prime} 30.6^{\prime \prime} \mathrm{N} 80^{\circ} 33^{\prime} 15.0^{\prime \prime} \mathrm{W}\right)$ to provide a natural source of microbial communities. The sediment was biostimulated in synthetic groundwater containing $3.5 \mathrm{mM}$ sodium sulfate and $250 \mathrm{mM}$ sodium lactate. The sediment was incubated at $25^{\circ} \mathrm{C}$; the solution was replaced once a week with fresh synthetic groundwater. Within one week, the sediment was found to be reducing as indicated by formation of black iron sulfide precipitates and a hydrogensulfide-like smell; however, the sediment was allowed to continue to reduce for several more weeks. The biostimulated sediment was mixed with acid-washed silica sand (20 - 30 mesh) at a ratio of $40 \%: 60 \%$ by volume, to increase permeability and allow water to flow through the material. The sediment-sand mixture was packed into the FTC under a $3.5 \% \mathrm{H}_{2} /$ balance $\mathrm{N}_{2}$ atmosphere in an anaerobic glovebox (Coy Laboratory Products Inc., Grass Lake, MI). Glass wool and Nitex mesh screen with $210 \mu \mathrm{m}$ openings was used to prevent clogging of the influent and effluent ports.

An input solution of synthetic groundwater containing $0.90 \mathrm{mM} \mathrm{Zn}$ as $\mathrm{ZnSO}_{4} \cdot 7 \mathrm{H}_{2} \mathrm{O}$ was prepared following the composition listed in Table 1. Lactate was added as the organic carbon source ( $250 \mathrm{mM}$ as Na-lactate), while $\mathrm{Na}_{2} \mathrm{SO}_{4}$ was added to increase the initial $\mathrm{SO}_{4}$ concentration to $4.4 \mathrm{mM}$. This solution was purged with high-purity Ar gas and equilibrated in the anaerobic glovebox. Prior to commencing the experiment, the packed FTC was saturated by using a peristaltic pump (Ismatec, Cole-Palmer, Montreal, QC) and $0.25 \mathrm{~mm}$ ID Pharmed pump tubing (Cole-Parmer, Vernon Hills, IL) to pump an input solution containing Zn upward through the bottom (input) port. Flow was halted after the FTC reached saturation, the input and effluent ports were closed, and the cell was allowed to sit stagnant for $72 \mathrm{~h}$ to enhance the development of 
sulfate-reducing conditions. Slow flow was applied (1-4 $\left.\mathrm{mL} \mathrm{h}^{-1}\right)$ for the following $72 \mathrm{~h}$. Finally, the cell was sealed, placed in an Ar-filled anaerobic canister, and transported to the synchrotron facility (stagnant for approximately 24h). Anaerobic conditions were maintained during the experiment at the synchrotron facility by mounting the cell in a He-purged plastic bag, into which the incident X-ray beam and detector were directed. Additionally, the input solution was protected with an Ar-filled Mylar balloon, while the aqueous effluent samples were collected in an Ar-purged tent (Figure 1).

Flow-through microelectrodes (Microelectrodes, Inc., Bedford, $\mathrm{NH}$ ) measuring $\mathrm{pH}$ and redox conditions were installed in-line at the effluent end of the cell, and data was logged to portable Orion Star A321 meters (Thermo Scientific) at 5 minute intervals throughout the experiment. The electrodes were conditioned with $10 \% \mathrm{HCl}$ for approximately 10 minutes prior to calibration with $\mathrm{pH} 4,7$, and 10 buffers. The performance of the redox electrode was verified using Zobell's (Nordstrom, 1977) and Light's (Light, 1972) solutions.

To examine changes in $\mathrm{Zn}$ isotope behaviour, changes in the effluent $\mathrm{Zn}$ concentration were required. These changes were achieved by progressively increasing the flow rate step-wise from approximately $0.8 \mathrm{~mL} \mathrm{~h}^{-1}$ to $4.1 \mathrm{~mL} \mathrm{~h}^{-1}$ over the course of the experiment. The duration of the sampling interval was calculated for each flow rate to ensure sufficient volume for all required analyses (Table 2). The flow rate was increased after 12, 20, 26, 32, 36, 40, and 43 total hours of elapsed time.

\section{$2.3 \quad$ X-ray absorption spectroscopy}

Synchrotron-based X-ray absorption near edge structure (XANES) spectroscopy was performed at beamline 13-ID-E at the Advanced Photon Source (APS), Argonne National Laboratory (Argonne, IL) to acquire real-time, in situ $\mathrm{Zn}$ spectra during the experiment. Analysis 
was performed at the $\mathrm{Zn} \mathrm{K}$-edge $(9659 \mathrm{eV})$ in bulk mode with an unfocused incident beam $(\sim 0.5$ $\times 10 \mathrm{~mm}$ ). The incident X-ray beam intersected the Kapton ${ }^{\circledR}$ window of the cell at a $45^{\circ}$ angle; the 4-element silicon drift fluorescence detector (Vortex ME-4, SII NanoTechnology USA Inc., Northridge, CA) was positioned at a $45^{\circ}$ angle to the window (Figure 1). A motorized sample stage allowed for movement of the FTC during the experiment, providing the opportunity to collect spectra at multiple locations. Six locations were selected along the flow path (vertical axis) for spectroscopic analysis (Supporting Information (SI), Figure S1). Three 16-minute scans were collected at each location; each location was visited up to 10 times during the course of the experiment. The entire measurement cycle took 5 hours, and the overall experiment lasted 50 hours. The detector was moved further from the sample stage to make additional measurements at positions four and five (near the effluent end of the cell) due to detector saturation, which was observed at these locations by the end of the experiment.

Zinc reference materials were finely ground, spread on polyethylene terephthalate (PET) tape (Scotch Magic Tape, 3M, St. Paul, MN), and layered to achieve thicknesses of $300-500 \mu \mathrm{m}$. Analysis of reference materials was performed in transmission mode, including zinc oxide $[\mathrm{ZnO}]$, zinc sulfide $[\mathrm{ZnS}]$, zinc sulfate heptahydrate $\left[\mathrm{ZnSO}_{4} \cdot 7 \mathrm{H}_{2} \mathrm{O}\right]$, zinc carbonate basic $\left[\left(\mathrm{ZnCO}_{3}\right)_{2} \cdot\left(\mathrm{Zn}(\mathrm{OH})_{2}\right)_{3}\right]$, zinc carbonate $\left[\mathrm{ZnCO}_{3}\right]$, zinc adsorbed to ferrihydrite $[\mathrm{Zn}$ on $\mathrm{Fh}]$, and zinc hydroxide $\left[\mathrm{Zn}(\mathrm{OH})_{2}\right]$.

Post-processing of the Zn XANES data was carried out using the program ATHENA, which is a component of the IFEFFIT software package (Ravel and Newville, 2005). To prepare the data for linear combination fitting (LCF), the three scans from each location were treated as a single time point and merged in $\mu(\mathrm{E})$. Merging the scans reduced noise, resulting in data that was easier to fit and interpret. The scans that were merged were not found to be significantly different 
from each other, though scans at a given location that were unusually noisy were excluded from the merge. Damage to the spectra due to synchrotron radiation was not observed. This process resulted in nine to ten discrete time steps for each of the six locations along the length of the cell. The merged scans were then energy shifted with respect to a $\mathrm{Zn}$ foil measured during the same synchrotron session before they were normalized. Linear combination fitting of the XANES region was initially performed using all available standards potentially present in the system before narrowing the scope of possibilities based on the similarity of the standards, the goodness of fit, and the probability of a given phase existing in the system. Linear combination fitting, when performed on properly normalized spectra, can provide a quantitative assessment of the species, and perhaps the phases present in the solid material, with an error of $\pm 5 \%$. Sulfur XAS was subsequently used to assist in determination of the phases at each location within the cell.

After the conclusion of the experiment, the cell was maintained under anaerobic conditions and returned to the University of Waterloo. Solid materials within the cell were divided from input end to effluent end into three sections (bottom, middle, and top), divided in half, and placed in six sample bottles in an anaerobic chamber before being frozen at $-80^{\circ} \mathrm{C}$. Frozen samples were subsequently freeze-dried and subsampled for XANES analysis at the sulfur K-edge (2472 eV), performed at the SXRMB beamline at the Canadian Light Source (Saskatoon, SK). Measurements at the S K-edge were made under vacuum $\left(<10^{-7}\right.$ Torr $)$. Standards measured include elemental sulfur $[\mathrm{S}(0)]$, pyrrhotite $[\mathrm{FeS}]$, pyrite $\left[\mathrm{FeS}_{2}\right]$, zinc sulfide $[\mathrm{ZnS}]$, and zinc sulfate heptahydrate $\left[\mathrm{ZnSO}_{4} \cdot 7 \mathrm{H}_{2} \mathrm{O}\right]$. Elemental sulfur was measured daily to ensure the beam energies were not shifting over time, and to determine if the oxidation of sulfur would be of concern during the course of sample measurement. The dwell time for each scan was optimized 
to obtain higher intensities while working within the allotted beam time, and two scans were collected for each sample.

The resulting sulfur XAS data was also processed using ATHENA (Ravel and Newville, 2005). The two scans from each sample were merged, energy shifted with respect to the most recently measured $\mathrm{S}(0)$ standard, then normalized. Linear combination fitting was performed using the measured standards, noting which standards could not be differentiated and which exhibited reasonably distinct spectra. Combinations were not forced to sum to one, so percentages were calculated relative to the sum of the fitted weights.

\subsection{Aqueous sampling}

Throughout the course of the experiment at the APS, aqueous effluent samples were collected continuously using a fraction collector (Retriever 500, Teledyne ISCO, Lincoln, NE), which was contained in an Ar-filled portable glove bag. Samples were retrieved from the fraction collector approximately every four hours to prevent significant evaporation. All samples were filtered at $0.2 \mu \mathrm{m}$; odd-numbered samples were acidified to $\mathrm{pH}<2$ with trace-metal grade $\mathrm{HNO}_{3}$, while even-numbered samples were left unacidified. Samples were stored at $4{ }^{\circ} \mathrm{C}$ and transported to the University of Waterloo for analysis. Cation concentrations, including Zn, were determined on acidified samples by inductively-coupled plasma optical emission spectrometry (ICP-OES; Thermo Scientific iCAP 6500) and inductively-coupled plasma mass spectrometry (ICP-MS; Thermo Scientific XSeries 2); anion concentrations were determined on unacidified samples by ion chromatography (IC; Dionex DX 600). 


\subsection{Microbiology}

After the FTC was disassembled at the conclusion of the experiment, genomic DNA was extracted from sediment samples (1 g subsample) using Power Soil DNA Isolation Kits from MOBIO Laboratories, Inc. Extracted DNA samples were frozen and shipped to Molecular Research LP in Shallowater, TX, where 16s rRNA pyrosequencing was conducted using a Roche 454 FLX Genome Sequencer (Dowd et al., 2008).

\subsection{Zn isotope analysis}

Acidified aqueous samples were prepared for $\mathrm{Zn}$ isotope analysis following the method described in Matthies et al. (2014). Briefly, samples were combined with a ${ }^{67} \mathrm{Zn}-{ }^{70} \mathrm{Zn}$ double spike solution of known isotopic composition to correct for instrumental mass bias. Following conversion to an $\mathrm{HCl}$ matrix, the spike-sample mixtures were loaded onto BioRad AG1-X8 anion exchange resin (200-400 mesh). Unwanted matrix elements were washed out using decreasing concentrations of $\mathrm{HCl}$; $\mathrm{Zn}$ was eluted in the final step of the purification sequence. After conversion back to an $\mathrm{HNO}_{3}$ matrix, the purified samples were diluted with high-resistivity (18.2 $\mathrm{M} \Omega$ ) water and prepared for isotope analysis. Each set of purifications contained two spiked aliquots of the IRMM 3702 certified isotope standard and one blank; eight of the 18 unknown samples were purified in duplicate.

Zinc isotope analysis was performed on a multi-collector ICP-MS (MC-ICP-MS; Thermo Scientific Neptune). All five $\mathrm{Zn}$ isotopes $\left({ }^{64} \mathrm{Zn},{ }^{66} \mathrm{Zn},{ }^{68} \mathrm{Zn},{ }^{67} \mathrm{Zn},{ }^{70} \mathrm{Zn}\right)$ were monitored simultaneously, along with ${ }^{62} \mathrm{Ni}$ and ${ }^{72} \mathrm{Ge}$ to correct for isobaric interferences. Instrumental mass bias was corrected using a double-nested iterative routine (Siebert et al., 2001), and the true isotopic composition of the samples was initially expressed as $\delta^{66} \mathrm{Zn}$ in per mil (\%o) relative to the IRMM $3702 \mathrm{Zn}$ isotope standard, where: 
$\delta^{66} \mathrm{Zn}=\left[\frac{\left({ }^{66} \mathrm{Zn} /{ }^{64} \mathrm{Zn}\right)_{\text {sample }}}{\left({ }^{66} \mathrm{Zn} /{ }^{64} \mathrm{Zn}\right)_{\text {standard }}}-1\right] \times 1000$

Results were normalized to daily measurements of the IRMM 3702 standards. Samples were analysed during three separate analytical events; reported results represent the average of three data points for samples purified only once, and six data points for samples purified in duplicate. Uncertainty of the data set was calculated to be $\pm 0.06 \%$ based on two times the root-meansquare difference of the eight samples prepared in duplicate. For the purposes of plotting and data interpretation, all effluent samples were subsequently normalized to the experimental input solution.

\section{Results}

\subsection{Aqueous geochemistry}

The $\mathrm{pH}$ of the input solution was determined to be 8.30 (Figure 2). At the slowest flow rate of $0.8 \mathrm{~mL} \mathrm{~h}^{-1}$ the effluent $\mathrm{pH}$ averaged $6.85 \pm 0.27(2 \sigma)$. A slight decrease in effluent $\mathrm{pH}$ was observed as the flow rate was increased to $1.4 \mathrm{~mL} \mathrm{~h}^{-1}(6.73 \pm 0.24)$, after which the remaining flow rates produced an average effluent $\mathrm{pH}$ of $6.68 \pm 0.08$. Redox measurements of the effluent started at $600 \mathrm{mV}$, followed by a decrease to $340 \mathrm{mV}$ at the conclusion of the experiment, suggesting a general trend toward reducing conditions (Figure 2).

Several ions, including chloride $(\mathrm{Cl})$, potassium $(\mathrm{K})$, and magnesium $(\mathrm{Mg})$ (at higher flow rates), passed through the cell near-conservatively, deviating in the effluent very little from the input concentration (Figure 2). In contrast, calcium (Ca) and iron (Fe) were at a much higher concentration in the effluent than the input solution; this suggests that reactions occurring within the sediment released these elements into solution. Calcium was consistently observed to be at higher concentrations in the effluent than the input, with maximum concentrations of 
approximately $2 \mathrm{mM}$ at slower flow rates, decreasing to approximately $0.4 \mathrm{mM}$ at the highest flow rate (Figure 2). This release of $\mathrm{Ca}$ from the reactive material may have been due to dissolution of Ca-containing minerals such as calcium carbonate. A brief but substantial release of Fe was observed at the beginning of the experiment, attaining concentrations of up to 0.17 $\mathrm{mM}$ in the effluent (Figure 2), suggesting reductive dissolution of Fe oxy(hydroxides) from the sediment. Nitrate was observed to decrease significantly in the effluent from the input concentration of $0.46 \mathrm{mM}$ at early time, dropping below detection after the first two samples. A slight increase in nitrite was observed at early time, indicating the possible presence of nitrate reduction (Figure 2).

A slight decrease in the sulfate concentration from $4.39 \mathrm{mM}$ in the influent to as low as 3.44 $\mathrm{mM}$ in the effluent was observed throughout the experiment; the greatest decrease in concentration occurred at the beginning of the experiment during the slowest flow rate (Figure 2). This behaviour is in agreement with the hypothesis that slow flow, and thus a greater residence time in the cell, would lead to a greater extent of sulfate reduction. A decrease in total aqueous sulfur was also observed throughout the experiment, exhibiting the lowest concentrations during the periods of slowest flow. This change in total sulfur concentrations indicates that sulfur was removed from solution, probably through sulfide mineral precipitation. It was not possible to measure aqueous sulfide concentrations to perform a mass balance calculation due to severe sample volume limitations.

\subsection{Zn removal}

The input $\mathrm{Zn}$ concentration was determined to be $0.90 \pm 0.01 \mathrm{mM}$ based on the average of two samples collected at the beginning and end of the experiment; the constancy of the $\mathrm{Zn}$ concentration indicated that no $\mathrm{Zn}$ precipitation occurred in the input solution over the course of 
the experiment. The effluent $\mathrm{Zn}$ concentration remained lower than the input $\mathrm{Zn}$ concentration throughout the experiment, despite changes in flow rate (Figure 2). The greatest degree of $\mathrm{Zn}$ removal was observed at the slowest flow rate, where $72-77 \%$ of the aqueous $\mathrm{Zn}$ was removed from solution. As the flow rate was increased, the degree of $\mathrm{Zn}$ removal decreased (i.e., the effluent $\mathrm{Zn}$ concentration increased). At the highest flow rate, approximately 33-37 \% of the aqueous $\mathrm{Zn}$ was removed from solution.

\subsection{In situ Zn speciation}

Experimental spectra were compared to an array of $\mathrm{Zn}$ standard spectra (Figure 4). Position 0 was not analyzed due to the low abundance of $\mathrm{Zn}$ at this location; however, visual inspection showed that scans at this location bear a slight resemblance to position 1 (Figure 3). Detector saturation at position 5 resulted in suppressed peaks (Figure 3); however, early scans at position 5 were very similar to those at position 4 . Spectra from near the input end of the cell (position 1, 2, and 3) bear a resemblance to a mixture of some form of zinc carbonate, hydroxide or carbonate hydroxide, $\mathrm{ZnSO}_{4} \cdot 7 \mathrm{H}_{2} \mathrm{O}$, and $\mathrm{Zn}$ adsorbed onto ferrihydrite (SI Figure S2). It was not possible to distinguish contributions from $\mathrm{ZnCO}_{3},\left(\mathrm{ZnCO}_{3}\right)_{2} \cdot\left(\mathrm{Zn}(\mathrm{OH})_{2}\right)_{3}$, and $\mathrm{Zn}(\mathrm{OH})_{2}$ because these spectra are similar, and could not be differentiated (SI Figure S3). For simplicity, only the $\mathrm{Zn}(\mathrm{OH})_{2}$ spectrum has been plotted (Figure 4). The spectra from position 4 strongly resemble the $\mathrm{ZnS}$ standard spectrum (Figure 4). The spectra from position 3 evolved over the course of the experiment, developing features characteristic of $\mathrm{ZnS}$ at later time (SI Figure S2). Note that the varieties of $\mathrm{ZnS}$, including würtzite and sphalerite, were not differentiated in this study. While $\mathrm{ZnS}$ spectra can appear drastically different if the iron content is greater than $34 \%$ (LawniczakJabłońska et al., 1995), our ZnS standards appear very similar to other ZnS standards (Gilbert et al., 2002; Roberts et al., 2002). 


\subsection{Solid-phase S speciation}

All three sections of the cell produced similar spectra for S K-edge XANES (Figure 5). The main difference is the height of the peak potentially associated with $S(0)$, and the peak associated with pyrrhotite. This observation indicates that a similar composition was found throughout the cell, with more pyrrhotite near the input, and more $S(0)$ at the effluent end of the cell. Unfortunately, the absorbance data was not useful as a proxy for the amount of sulfur at all three locations because sample-specific optimization was performed at the time of analysis.

\subsection{Microbiology}

The initial lake sediment was dominated by sulfur and iron-oxidizing bacteria, including those belonging to members of Thiobacillus, Sulfuricurvum, Sideroxydans and Acidovorax, among others (Figure 6). Following biostimulation, the microbial community in the reduced sediment was dominated by members of bacteria belonging to Desulfovibrio and Anaerospora spp (Figure 6). Desulfovibrio is a genus of Gram negative sulfate-reducing anaerobic bacteria, commonly found in aquatic environments with high levels of organic material, as well as in water-logged soils. Species of bacteria belonging to the Desulfovibrio genus primarily respire sulfate and produce sulfide. However a number of species belonging to the Desulfovibrio genus have also been reported to reduce heavy metals such as uranium and chromium (Lovley et al., 1993; Lovley and Phillips, 1994). Species belonging to the Anaerospora genus are relatively rare, but have been reported to occur in coastal environments (Boehm et al., 2014). Desulfovibrio spp were dominant in the sediment along the length of the FTC during the experiment (Figure 6). 


\subsection{Zn isotope ratios}

Zinc isotope measurements were performed on the aqueous $\mathrm{Zn}$ in both the input and effluent samples. The $\mathrm{Zn}$ isotope ratio of the input solution was $\delta^{66} \mathrm{Zn}=-0.19 \pm 0.05 \%$ relative to the IRMM 3702 standard. To simplify the discussion of experimental results, all samples were normalized to the input solution value, resulting in a value of $\delta^{66} \mathrm{Zn}=0.00 \pm 0.05 \%$ for the input. Zinc isotope ratio values for the effluent, normalized to the input solution, are presented with effluent $\mathrm{Zn}$ concentrations in Figure 7, plotted over time. At early time, the effluent isotope values were enriched in the heavier isotope as compared to the input, with values up to $\delta^{66} \mathrm{Zn}=+$ $0.48 \pm 0.03 \%$. This isotope signature corresponds with the slowest flow rate, and the greatest degree of $\mathrm{Zn}$ removal. As the flow rate was increased and the effluent $\mathrm{Zn}$ concentrations increased (i.e., lesser degree of $\mathrm{Zn}$ removal), the effluent isotope ratio values approached the input isotope composition. At the conclusion of the experiment, as the highest flow rate was achieved and less than $40 \%$ of the aqueous $\mathrm{Zn}$ was being removed from solution, the isotope signature of the effluent was $\delta^{66} \mathrm{Zn}=+0.09 \pm 0.02 \%$.

\section{Discussion}

\subsection{Removal rates}

Sulfate removal rates were calculated for each of the flow rates by subtracting the effluent sulfate concentration from the input concentration, and dividing the result by the residence time. Removal rates ranged from $0.03-0.05 \mathrm{mM} \mathrm{h}^{-1}$ at the slowest flow rate $\left(0.8 \mathrm{~mL} \mathrm{~h}^{-1}\right)$, increasing up to $0.07-0.08 \mathrm{mM} \mathrm{h}^{-1}$ at the fastest flow rate $\left(4.1 \mathrm{~mL} \mathrm{~h}^{-1}\right)$. These rates compare well with those calculated by Waybrant et al. (1998) for batch experiments to evaluate reactive mixtures for use in permeable reactive walls to treat mine drainage, where removal rates ranging from 
$0.01 \mathrm{mM} \mathrm{h}^{-1}$ to $0.07 \mathrm{mM} \mathrm{h}^{-1}$ were observed. Unlike the current study where Na-lactate was used as an organic carbon source, Waybrant et al. (1998) used solid organic substrates, such as sewage sludge, wood chips, and leaf mulch; the organic carbon source was attributed, in part, to the variability in the calculated sulfate removal rates. Subsequent column experiments using different mixtures of these same solid organic substrates exhibited a similar range of sulfate removal rates, with values from $0.02 \mathrm{mM} \mathrm{h}^{-1}$ to $0.05 \mathrm{mM} \mathrm{h}^{-1}$ (Waybrant et al., 2002). In contrast, a full-scale permeable reactive barrier installed at the Nickel Rim mine site in Ontario, Canada, designed to use bacterially-mediated sulfate reduction to promote metal-sulfide precipitation, exhibited sulfate removal rates in the range of $0.005-0.007 \mathrm{mM} \mathrm{h}^{-1}$ (Benner et al., 2002). The difference between these rates and those calculated in the current study may be related to the organic carbon source used in the barrier (municipal compost), or to the lower average water temperature.

Zinc removal rates were calculated following the same approach. There was very good agreement between the $\mathrm{Zn}$ and sulfate removal rates, with $\mathrm{Zn}$ values of $0.04-0.05 \mathrm{mM} \mathrm{h}^{-1}$ at the slowest flow rate $\left(0.8 \mathrm{~mL} \mathrm{~h}^{-1}\right)$, and $0.08-0.09 \mathrm{mM} \mathrm{h}^{-1}$ at the fastest flow rate $\left(4.1 \mathrm{~mL} \mathrm{~h}^{-1}\right)$. This suggests that these constituents were monotomically removed from the system, most likely via the pathway of sulfate reduction followed by $\mathrm{ZnS}$ precipitation (Eq. 1 \& 2).

An increasing trend in both the sulfate and $\mathrm{Zn}$ removal rates was observed in the flow-through cell experiment as the flow rate was increased. This trend could be due to a build-up of residual sulfide in the system at later times; however, the consistent 1:1 correlation between the sulfate and $\mathrm{Zn}$ removal rates suggest that this likely did not occur. The more likely explanation for this increasing trend is that the system was nutrient-limited at early time, during the slower flow regime. A limit in either the sulfate or the lactate may have restricted the rate of sulfate removal; 
as the flow was increased, and more sulfate and lactate were supplied to the system, the rate of sulfate removal (and thus $\mathrm{Zn}$ removal) increased. In addition, more rapid flushing of metabolic by-products may have occurred at the faster flow rates, contributing to the increase in the sulfate removal rate. Despite the observed variation, the range of sulfate removal rates is in good agreement with published values for similar systems.

\subsection{Linear combination fitting of XAS spectra}

A comparison of the fluorescence counts at the input end of the cell to those at the effluent end indicates that only a small mass of $\mathrm{Zn}$ accumulated at the influent end, and a much larger mass of $\mathrm{Zn}$ accumulated at the effluent end (Figure 3). Linear combination fitting was used to estimate the relative abundance of phases present in each position along the cell (Figure 8; SI Figure S4). The goodness of fit is demonstrated by Figure S5 (SI), where the derivative of two representative spectra are plotted with the results of the LCF. While the fitting procedure suggested the presence of elemental $\mathrm{Zn}$ at all locations, this phase was excluded from the final fit due to the very low likelihood of formation in the system (Li and Zhang, 2007). The Zn XANES spectra collected at the influent end suggest that sorption or precipitation of a $\mathrm{Zn}$ hydroxide, $\mathrm{Zn}$ carbonate, or hydroxycarbonate phase was the dominant $\mathrm{Zn}$ removal mechanism at this location (Figure 8). However, this removal mechanism likely only played a minor role in the overall mass of $\mathrm{Zn}$ removed from solution (Figure 3). It is also possible that some of these $\mathrm{Zn}$ phases preexisted on the sediment before the beginning of the experiment.

The Zn XANES spectra suggest that $\mathrm{Zn}$ accumulated at the effluent end of the cell was predominantly in the $\mathrm{ZnS}$ form, though a small amount of a $\mathrm{Zn}$ carbonate/hydroxide was initially detectable in this region (Figure 8). The S XANES spectra analysis suggests that the proportion of $\mathrm{S}$ in the $\mathrm{ZnS}$ phase is roughly identical at the three post-experiment positions (Figure 9). The 
goodness of fit for the S XANES LCF is demonstrated in Figure S6 (SI). It is possible that the accumulation of these phases is entirely dependent on the amount of sulfur available, and any differences in the composition at the effluent, middle, and influent regions of the cell are related to the availability of other elements.

The greater accumulation of $\mathrm{ZnS}$ at the effluent end of the cell probably reflects the residence time required for sulfate reduction and $\mathrm{ZnS}$ precipitation. The magnitude of the $\mathrm{ZnS}$ signal compared to the $\mathrm{Zn}$ carbonate/hydroxide signal indicates that $\mathrm{ZnS}$ precipitation was the predominant mechanism of $\mathrm{Zn}$ removal over the duration of the experiment (Figure 3). The greater abundance of $S(0)$ near the effluent end of the cell also suggests that residence time is a factor. Elemental sulfur can be produced through incomplete microbial sulfate reduction (Bishop et al., 2013), or by the oxidation of sulfides (Pyzik and Sommer, 1981; Steudel, 1996). Care was taken to preserve the samples in an anoxic environment prior to analysis, suggesting that $S(0)$ formed in situ.

Although $\mathrm{ZnSO}_{4} \cdot 7 \mathrm{H}_{2} \mathrm{O}$ may also be present according to the $\mathrm{S}$ XANES, it was not found during the analysis of the $\mathrm{Zn}$ XANES spectra. It should be noted that the $\mathrm{ZnSO}_{4} \bullet 7 \mathrm{H}_{2} \mathrm{O}$ spectra bears a similar appearance to other $\mathrm{SO}_{4}$ spectra, so the spectra may reflect the presence of $\mathrm{SO}_{4}$ from the input solution, un-associated with $\mathrm{Zn}$. The majority of S present in the system is associated with Fe as pyrrhotite (Figure 9). There are two possible explanations for this observation; pyrrhotite formation could arise due to the presence of Fe-sulfides in the sediment, which was collected from an anaerobic lake environment, or dissolved iron oxides reprecipitated as iron sulfides in the sulfur-reducing environment. However, due to the stoichiometric relationship between $\mathrm{Zn}$ and $\mathrm{S}$ removal rates within this system, the first hypothesis is a more likely explanation for the presence of pyrrhotite. 


\subsection{Zn isotope fractionation}

The isotope data was fit using the Rayleigh equation (Rayleigh, 1902; Figure 10), due to the isolation of the reaction product from the reactants:

$\frac{R}{R_{0}}=f^{(\alpha-1)}$

where $R$ is the ${ }^{66} \mathrm{Zn} /{ }^{64} \mathrm{Zn}$ isotope ratio, $R_{0}$ is the initial ${ }^{66} \mathrm{Zn} /{ }^{64} \mathrm{Zn}$ isotope ratio, $\alpha$ is the isotopic fractionation factor, and $f$ is the fraction of $\mathrm{Zn}$ remaining in solution. For convenience, the extent of fractionation is expressed in terms of the isotopic fractionation value using the epsilon notation $(\varepsilon)$ according to the following equation:

$\varepsilon=(\alpha-1) \times 1000$

The uncertainty on the isotopic fractionation value was calculated as two times the standard error of the best-fit used to determine the isotopic fractionation factor, following the method of Kitchen et al. (2012). An isotopic fractionation value of $\varepsilon=-0.27 \pm 0.06 \%$ was found to provide the best fit to the flow-through cell data (Figure 10).

During their investigation of $\mathrm{Zn}$ isotope variation in hydrothermal systems, Wilkinson et al. (2005) suggested that the precipitation of $\mathrm{ZnS}$ may involve preferential removal of the lighter isotopes from solution, resulting in a solution enriched in the heavier isotopes. Archer et al. (2004) observed a similar trend in $\mathrm{Zn}$ isotope fractionation during precipitation of $\mathrm{ZnS}$.

Theoretical calculations performed by Fujii et al. (2011) also suggested that the lighter Zn isotopes will be enriched in the sulfide species (up to $\delta^{66} \mathrm{Zn}=-0.6 \%$ ).

The most relevant comparison for the current study comes from a series of batch experiments performed by Veeramani et al. (2015), in which Zn isotope behaviour was characterized during precipitation of $\mathrm{ZnS}, \mathrm{Zn}$-carbonate, and Zn-phosphate. Precipitation of these $\mathrm{Zn}$ phases was 
achieved by adding varying concentrations of counteranions $\left(\mathrm{Na}_{2} \mathrm{~S}_{2}, \mathrm{NaHCO}_{3}\right.$, and $\left.\mathrm{Na}_{3} \mathrm{PO}_{4}\right)$ to pure solutions of $\mathrm{ZnSO}_{4}$ or $\mathrm{ZnCl}_{2}$, under static conditions; aqueous samples were collected after 24 hours for $\mathrm{Zn}$ isotope ratio analysis. Results from these batch experiments demonstrated an enrichment in the heavier isotope in the aqueous $\mathrm{Zn}$ during $\mathrm{ZnS}$ precipitation, while a depletion was observed during precipitation of carbonate and phosphate phases. The isotopic fractionation for $\mathrm{ZnS}$ precipitation was determined to be $\varepsilon=-0.30 \pm 0.04 \%$; a Rayleigh curve describing this degree of fractionation is plotted along with the flow-through cell data in Figure 10 (dashed line).

The close agreement between the $\varepsilon$ values for this study and $\mathrm{ZnS}$ precipitation from Veeramani et al. (2015) suggests that the overwhelming majority of the $\mathrm{Zn}$ removal from solution occurred via ZnS precipitation. Although the XAS data suggests the presence of a sorbed phase or a $\mathrm{Zn}$ carbonate or hydroxide phase near the input end of the cell, the contribution of this material to the overall mass of $\mathrm{Zn}$ removed from solution must have been very modest in order to have little to no effect on the bulk isotope signature.

Veeramani et al. (2015) also performed batch experiments to determine the time required to achieve isotopic equilibrium for the precipitation of each $\mathrm{Zn}$ phase (results included in their Supporting Information). Isotopic equilibrium was rapidly achieved for $\mathrm{ZnS}$ precipitation, producing a stable $\delta^{66} \mathrm{Zn}$ value relative to the input solution within the first 15 minutes of the reaction. The shortest residence time for the flow-through cell in the current study was $\sim 3.5$ hours, which was observed at the fastest flow rate $\left(4.1 \mathrm{~mL} \mathrm{~h}^{-1}\right)$. As this residence time is significantly greater than the time required for isotopic equilibrium determined by Veeramani et al. (2015), it is likely that $\mathrm{Zn}$ isotopic equilibrium was achieved throughout the flow-through cell experiment. 


\subsection{Implications for field studies}

The application of $\mathrm{Zn}$ isotope ratio measurements to assist in the interpretation of measurements derived from natural systems and remediation endeavours requires an understanding of $\mathrm{Zn}$ isotope fractionation. Zinc removal under microbially-mediated sulfate reducing conditions is a valuable system to study as this process is widely observed in natural and remediation systems. Controlled studies such as that conducted by Veeramani et al. (2015) are critical for providing a clear characterization of $\mathrm{Zn}$ isotope fractionation associated with individual mechanisms. However, it is also important to evaluate more complex systems, such as the experiment conducted in this study, to extend the understanding of $\mathrm{Zn}$ isotope behaviour to a system where multiple geochemical processes may be involved. In addition, it is essential to consider the effect of saturated flow conditions, as flow dynamics can influence the degree of isotope fractionation (Jamieson-Hanes et al., 2012; Jamieson-Hanes et al., 2015). Results from this study demonstrate that the application of $\mathrm{Zn}$ isotope ratio measurements, combined with XAS and aqueous geochemical measurements, can provide valuable insight into the complex geochemical systems encountered in field studies.

The source of sulfide differed between this study and the precipitation batch experiment of Veeramani et al. (2015). Whereas the sulfide was introduced to the batch experiment abiotically with the addition of $\mathrm{Na}_{2} \mathrm{~S}_{2}$, the sulfide in the flow-through cell was produced during microbiallymediated sulfate reduction. However, the overall result was that the precipitation of $\mathrm{ZnS}$ in both experiments produced nearly identical $\mathrm{Zn}$ isotope fractionation values. In a more complex fieldscale system, it may be useful to measure both $\mathrm{Zn}$ and $\mathrm{S}$ isotope ratios in the aqueous- and the solid-phase. The coupling of these isotope measurements could potentially provide insight regarding the role of abiotic vs. biologically-mediated reactions, and perhaps give more 
information about the biogeochemical processes governing $\mathrm{Zn}$ remediation than $\mathrm{Zn}$ isotope ratio measurements alone are able to provide.

\section{Conclusions}

The purpose of this study was to characterize $\mathrm{Zn}$ isotope fractionation during $\mathrm{ZnS}$ precipitation under sulfate reducing conditions. Multiple lines of observation were used to determine that $\mathrm{Zn}$ removal most likely occurred via $\mathrm{ZnS}$ precipitation. Traditional aqueous geochemical parameters showed decreasing sulfate concentrations in the effluent were associated with decreasing aqueous total sulfur concentrations. Removal of $\mathrm{Zn}$ from solution was found to be most effective at slower flow rates, where the greater residence time led to an increased extent of sulfate reduction; a consistent 1:1 correlation between the sulfur and $\mathrm{Zn}$ removal rates provided further evidence of $\mathrm{ZnS}$ precipitation. Real-time, in situ XAS analysis at the Zn K-edge showed that the overwhelming majority of the $\mathrm{Zn}$ removed from solution was as $\mathrm{ZnS}$, which was most abundant at the effluent end of the cell. The isotope composition of the aqueous $\mathrm{Zn}$ became more enriched relative to the input solution as a greater proportion of $\mathrm{Zn}$ was removed from solution, following a Rayleigh trend where $\varepsilon=-0.27 \pm 0.06 \%$. This trend is similar to the isotope fractionation value determined for precipitation of $\mathrm{ZnS}$ in a batch system (Veeramani et al., 2015).

Results from this study provide valuable information on the $\mathrm{Zn}$ isotope behaviour under sulfate-reducing conditions. The use of a variety of analytical techniques was paramount in providing the best possible understanding of the geochemical processes within this system. Application of real-time, in situ XAS analysis allowed for critical evaluation of $\mathrm{Zn}$ treatment as the experiment progressed. Future work coupling the analysis of multiple isotope systems, such as $\mathrm{Zn}$ and $\mathrm{S}$, may provide even further insight into the mechanisms of $\mathrm{Zn}$ removal. Controlled 
laboratory studies such as the one described here are essential for understanding $\mathrm{Zn}$ isotope fractionation prior to the application of this promising new technique.

\section{Acknowledgements}

Funding for this research was provided by the Natural Sciences and Engineering Research Council of Canada (NSERC) Strategic Grant awarded to D.W. Blowes and C.J. Ptacek. Aspects of this research were performed at GeoSoilEnviroCARS (Sector 13), Advanced Photon Source (APS), Argonne National Laboratory. GeoSoilEnviroCARS is supported by the National Science Foundation - Earth Sciences (EAR-0622171) and Department of Energy - Geosciences (DEFG02-94ER14466). Use of the Advanced Photon Source was supported by the U.S. Department of Energy, Office of Science, Office of Basic Energy Sciences, under contract No. DE-AC0206CH11357. Research described in this paper was performed at the Canadian Light Source, which is supported by the Canada Foundation for Innovation, Natural Sciences and Engineering Research Council of Canada, the University of Saskatchewan, the Government of Saskatchewan, Western Economic Diversification Canada, the National Research Council Canada, and the Canadian Institutes of Health Research. We thank Y. Hu, A. Lentz, P. Liu, A. MacLennan, and O. Wang for their assistance with experimental and analytical aspects of this research, and $\mathrm{H}$. Vander Heide and the Machining group at University of Waterloo for helping to design and build the flow-through cells. Thank you also to the editor and three anonymous reviewers whose comments have greatly improved the quality of this manuscript.

\section{References}

Al T. A., Blowes D. W., Jambor J. L. and Scott J. D. (1994) The geochemistry of mine-waste pore water affected by the combined disposal of natrojarosite and base-metal sulphide tailings at Kidd Creek, Timmins, Ontario. Can. Geotech. J. 31, 502-512.

Aranda S., Borrok D. M., Wanty R. B. and Balistrieri L. S. (2012) Zinc isotope investigation of 
surface and pore waters in a mountain watershed impacted by acid rock drainage. Sci. Total Environ. 420, 202-13.

Archer C., Vance D. and Butler I. (2004) Abiotic Zn isotope fractionations associated with ZnS precipitation. In Geochim. Cosmochim. Acta pp. A325-A325.

Balistrieri L. S., Borrok D. M., Wanty R. B. and Ridley W. I. (2008) Fractionation of Cu and Zn isotopes during adsorption onto amorphous Fe (III) oxyhydroxide: Experimental mixing of acid rock drainage and ambient river water. Geochim. Cosmochim. Acta 72, 311-328.

Benner S. G., Blowes D. W., Ptacek C. J. and Mayer K. U. (2002) Rates of sulfate reduction and metal sulfide precipitation in a permeable reactive barrier. Appl. Geochemistry 17, 301-320.

Besser J. M. and Leib K. J. (2007) Toxicity of Metals in Water and Sediment to Aquatic Biota. In Integrated Investigations of Environmental Effects of Historical Mining in the Animas River Watershed, San Juan County, Colorado: U.S. Geological Survey Professional Paper 1651 (eds. S. E. Church, P. von Guerard, and S. E. Finger). pp. 839-849.

Bishop T., Turchyn A. V. and Sivan O. (2013) Fire and brimstone: the microbially mediated formation of elemental sulfur nodules from an isotope and major element study in the paleoDead Sea. PLoS One 8, 18-21.

Black J. R., Kavner A. and Schauble E. A. (2011) Calculation of equilibrium stable isotope partition function ratios for aqueous zinc complexes and metallic zinc. Geochim. Cosmochim. Acta 75, 769-783.

Blowes D. W., Ptacek C. J., Benner S. G., McRae C. W. T., Bennett T. A. and Puls R. W. (2000) Treatment of inorganic contaminants using permeable reactive barriers. J. Contam. Hydrol. 45, 123-137.

Blowes D. W., Ptacek C. J., Jambor J. L., Weisener C. G., Paktunc D., Gould W. D. and Johnson D. B. (2014) The Geochemistry of Acid Mine Drainage. In Treatise on Geochemistry (Second Edition) (eds. H. Holland and K. Turekian). Elsevier, Oxford. pp. 131-190.

Boehm A. B., Yamahara K. M. and Sassoubre L. M. (2014) Diversity and transport of microorganisms in intertidal sands of the California coast. Appl. Environ. Microbiol. 80, 3943-3951.

Borrok D. M., Wanty R. B., Ian Ridley W., Lamothe P. J., Kimball B. A., Verplanck P. L. and Runkel R. L. (2009) Application of iron and zinc isotopes to track the sources and mechanisms of metal loading in a mountain watershed. Appl. Geochemistry 24, 1270-1277.

Bryan A. L., Dong S., Wilkes E. B. and Wasylenki L. E. (2015) Zinc isotope fractionation during adsorption onto Mn oxyhydroxide at low and high ionic strength. Geochim. Cosmochim. Acta 157, 182-197.

Dowd S. E., Callaway T. R., Wolcott R. D., Sun Y., McKeehan T., Hagevoort R. G. and Edrington T. S. (2008) Evaluation of the bacterial diversity in the feces of cattle using $16 \mathrm{~S}$ rDNA bacterial tag-encoded FLX amplicon pyrosequencing (bTEFAP). BMC Microbiol. 125.

Fujii T., Moynier F., Blichert-Toft J. and Albarède F. (2014) Density functional theory estimation of isotope fractionation of $\mathrm{Fe}, \mathrm{Ni}, \mathrm{Cu}$, and $\mathrm{Zn}$ among species relevant to 
geochemical and biological environments. Geochim. Cosmochim. Acta 140, 553-576.

Fujii T., Moynier F., Pons M.-L. and Albarède F. (2011) The origin of Zn isotope fractionation in sulfides. Geochim. Cosmochim. Acta 75, 7632-7643.

Gilbert B., Frazer B., Zhang H., Huang F., Banfield J., Haskel D., Lang J., Srajer G. and Stasio G. (2002) X-ray absorption spectroscopy of the cubic and hexagonal polytypes of zinc sulfide. Phys. Rev. B 66, 1-6.

Jamieson-Hanes J. H., Amos R. T., Blowes D. W. and Ptacek C. J. (2015) Dual mechanism conceptual model for $\mathrm{Cr}$ isotope fractionation during reduction by zerovalent iron under saturated flow conditions. Environ. Sci. Technol. 49, 5467-5475.

Jamieson-Hanes J. H., Gibson B. D., Lindsay M. B. J., Kim Y., Ptacek C. J. and Blowes D. W. (2012) Chromium isotope fractionation during reduction of $\mathrm{Cr}(\mathrm{VI})$ under saturated flow conditions. Environ. Sci. Technol. 46, 6783-6789.

Jamieson-Hanes J. H., Lentz A. M., Amos R. T., Ptacek C. J. and Blowes D. W. (2014) Examination of $\mathrm{Cr}(\mathrm{VI})$ treatment by zero-valent iron using in situ, real-time X-ray absorption spectroscopy and $\mathrm{Cr}$ isotope measurements. Geochim. Cosmochim. Acta 142, 299-313.

Juillot F., Maréchal C., Ponthieu M., Cacaly S., Morin G., Benedetti M., Hazemann J. L., Proux O. and Guyot F. (2008) Zn isotopic fractionation caused by sorption on goethite and 2-Lines ferrihydrite. Geochim. Cosmochim. Acta 72, 4886-4900.

Kitchen J. W., Johnson T. M., Bullen T. D., Zhu J. and Raddatz A. (2012) Chromium isotope fractionation factors for reduction of $\mathrm{Cr}(\mathrm{VI})$ by aqueous $\mathrm{Fe}(\mathrm{II})$ and organic molecules. Geochim. Cosmochim. Acta 89, 190-201.

Labrenz M. and Druschel G. K. (2011) Zinc. In Encyclopedia of Geobiology (eds. J. Reitner and V. Thiel). Springer Netherlands. pp. 905-908.

Ławniczak-Jabłońska K., Iwanowski R. J., Gołacki Z., Traverse A., Pizzini S. and Fontaine A. (1995) Correlation between XANES of the transition metals in $\mathrm{ZnS}$ and $\mathrm{ZnSe}$ and their limit of solubility. Phys. B Condens. Matter 208-209, 497-499.

Lawrence A. W. and McCarty P. L. (1965) The role of sulfide in preventing heavy metal toxicity in anaerobic treatment. Water Pollut. Control 37, 392-406.

Li X. and Zhang W. (2007) Sequestration of metal cations with zerovalent iron nanoparticles: A study with high resolution X-ray photoelectron spectroscopy (HR-XPS). J. Phys. Chem. C 111, 6939-6946.

Light T. S. (1972) Standard solution for redox potential measurements. Anal. Chem. 44, 10381039.

Lindsay M. B. J., Condon P. D., Jambor J. L., Lear K. G., Blowes D. W. and Ptacek C. J. (2009) Mineralogical, geochemical, and microbial investigation of a sulfide-rich tailings deposit characterized by neutral drainage. Appl. Geochemistry 24, 2212-2221.

Lovley D. R. and Phillips E. J. P. (1994) Reduction of chromate by Desulfovibrio vulgaris and its c3 cytochrome. Appl. Environ. Microbiol. 60, 726-728. 
Lovley D. R., Roden E. E., Phillips E. J. P. and Woodward J. C. (1993) Enzymatic iron and uranium reduction by sulfate-reducing bacteria. Mar. Geol. 113, 41-53.

Maréchal C., Telouk P. and Albarède F. (1999) Precise analysis of copper and zinc isotopic compositions by plasma-source mass spectrometry. Chem. Geol. 156, 251-273.

Matthies R., Krahé L. and Blowes D. W. (2014) Zinc stable isotope fractionation upon accelerated oxidative weathering of sulfidic mine waste. Sci. Total Environ. 487, 97-101.

Meija J., Coplen T. B., Berglund M., Brand W. A., De Bièvre P., Gröning M., Holden N. E., Johanna I., D L. R., Thomas W. and Thomas P. (2016) Isotopic compositions of the elements 2013 (IUPAC Technical Report). Pure Appl. Chem. 88, 293.

Moncur M. C., Ptacek C. J., Blowes D. W. and Jambor J. L. (2005) Release, transport and attenuation of metals from an old tailings impoundment. Appl. Geochem. 20, 639-659.

Nordstrom D. K. (1977) Thermochemical redox equilibria of ZoBell's solution. Geochim. Cosmochim. Acta 41, 1835-1841.

Pokrovsky O. S., Viers J. and Freydier R. (2005) Zinc stable isotope fractionation during its adsorption on oxides and hydroxides. J. Colloid Interface Sci. 291, 192-200.

Pyzik A. J. and Sommer S. E. (1981) Sedimentary iron monosulfides: Kinetics and mechanism of formation. Geochim. Cosmochim. Acta 45, 687-698.

Ravel B. and Newville M. (2005) ATHENA, ARTEMIS, HEPHAESTUS: Data analysis for Xray absorption spectroscopy using IFEFFIT. J. Synchrotron Radiat. 12, 537-541.

Rayleigh, Lord (1902) LIX. On the distillation of binary mixtures. London, Edinburgh, Dublin Philos. Mag. J. Sci. 4, 521-537.

Roberts D. R., Scheinost A. C. and Sparks D. L. (2002) Zinc speciation in a smeltercontaminated soil profile using bulk and microspectroscopic techniques. Environ. Sci. Technol. 36, 1742-1750.

Siebert C., Nägler T. F. and Kramers J. D. (2001) Determination of molybdenum isotope fractionation by double-spike multicollector inductively coupled plasma mass spectrometry. Geochem. Geophys. Geosyst. 2, $2000 \mathrm{GC000124.}$

Steudel R. (1996) Mechanism for the formation of elemental sulfur from aqueous sulfide in chemical and microbiological desulfurization processes. Ind. Eng. Chem. Res. 35, 14171423.

Veeramani H., Eagling J., Jamieson-Hanes J. H., Kong L., Ptacek C. J. and Blowes D. W. (2015) Zinc isotope fractionation as an indicator of geochemical attenuation processes. Environ. Sci. Technol. Lett. 2, 314-319.

Waybrant K. R., Blowes D. W. and Ptacek C. J. (1998) Selection of reactive mixtures for use in permeable reactive walls for treatment of mine drainage. Environ. Sci. Technol. 32, 19721979.

Waybrant K. R., Ptacek C. J. and Blowes D. W. (2002) Treatment of mine drainage using permeable reactive barriers: column experiments. Environ. Sci. Technol. 36, 1349-1356. 
Wilkinson J. J., Weiss D. J., Mason T. F. D. and Coles B. J. (2005) Zinc isotope variation in hydrothermal systems: Preliminary evidence from the Irish Midlands ore field. Econ. Geol. 100, 583-590. 


\section{Tables}

Table 1. Composition of flow-through cell input solution.

\begin{tabular}{ll}
\hline Parameter & Value \\
\hline $\mathrm{pH}$ & 8.30 \\
$\mathrm{Na}(\mathrm{mM})$ & 272 \\
Lactate $(\mathrm{mM})$ & 250 \\
$\mathrm{SO}_{4}(\mathrm{mM})$ & 4.44 \\
$\mathrm{Zn}(\mathrm{mM})$ & 0.90 \\
$\mathrm{Mg}(\mathrm{mM})$ & 0.97 \\
$\mathrm{~K}(\mathrm{mM})$ & 0.42 \\
$\mathrm{Ca}(\mathrm{mM})$ & 0.07 \\
$\mathrm{Fe}(\mu \mathrm{M})$ & 11.76 \\
$\mathrm{Co}(\mu \mathrm{M})$ & 0.79 \\
$\mathrm{Mn}(\mu \mathrm{M})$ & 0.60 \\
$\mathrm{Cu}(\mu \mathrm{M})$ & 0.25 \\
$\mathrm{Mo}(\mu \mathrm{M})$ & 0.18 \\
$\mathrm{Ni}(\mu \mathrm{M})$ & 0.16 \\
$\mathrm{Cl}(\mathrm{mM})$ & 2.62 \\
$\mathrm{NO}$ & 0.46 \\
\hline
\end{tabular}


Table 2. Flow-through cell experimental design.

\begin{tabular}{ccc}
\hline $\begin{array}{c}\text { Estimated flow rate } \\
\left(\mathrm{mL} \mathrm{h}^{-1}\right)\end{array}$ & $\begin{array}{c}\text { Elapsed time at given } \\
\text { flow rate }(\mathrm{h})\end{array}$ & $\begin{array}{c}\text { Number of samples } \\
\text { collected }\end{array}$ \\
\hline 0.8 & 12 & 4 \\
1.4 & 8 & 3 \\
1.9 & 6 & 3 \\
2.5 & 6 & 4 \\
2.7 & 4 & 3 \\
3.3 & 4 & 4 \\
3.8 & 3 & 3 \\
4.1 & 6 & 8 \\
\hline
\end{tabular}


Figures

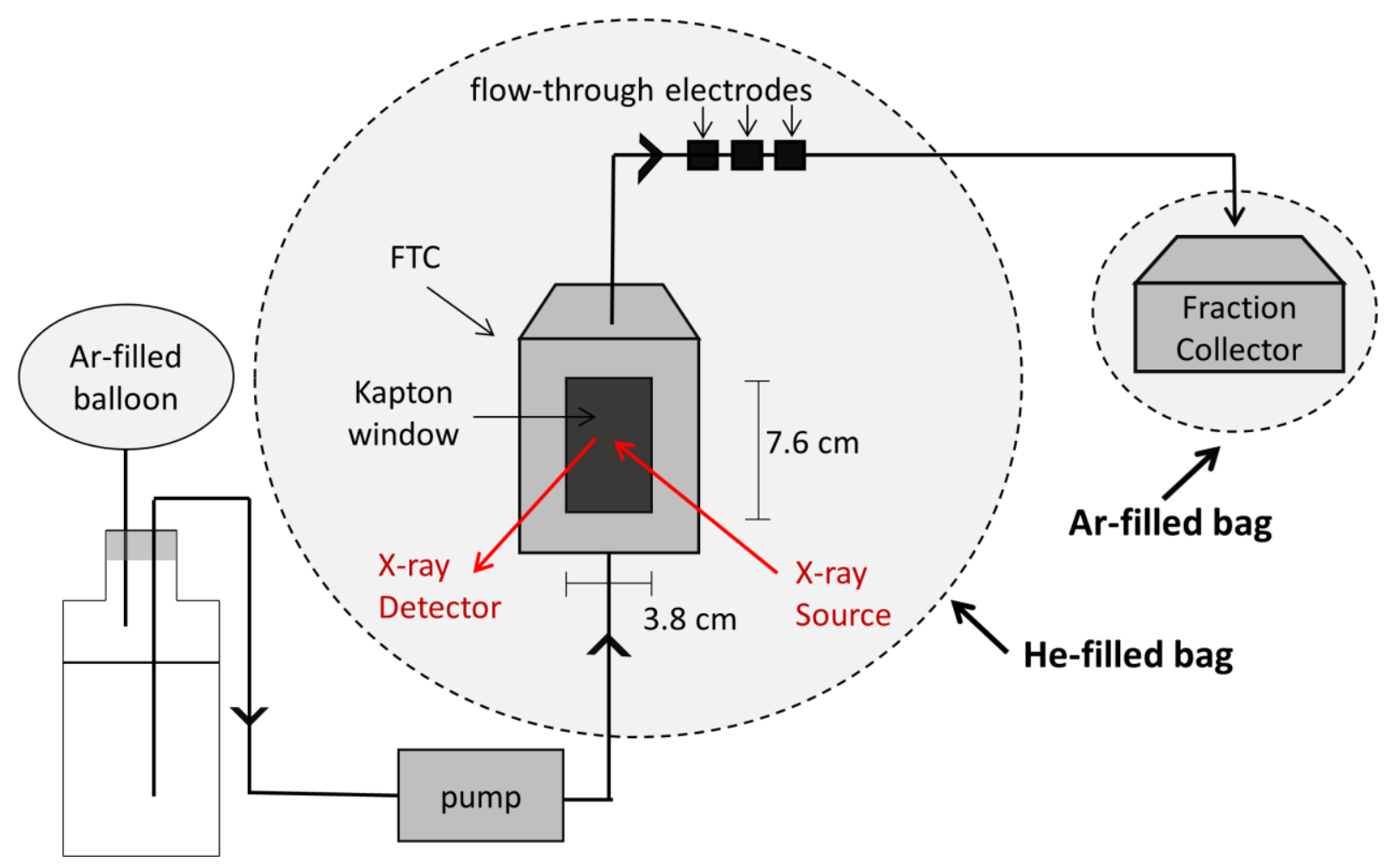

Figure 1. Schematic of the flow-through cell setup. Input solution was pumped upward through the cell; effluent passed through in-line $\mathrm{pH}$ and redox microelectrodes before being collected in the fraction collector. A Kapton window allowed the passage of the Xrays at an incident angle of $45^{\circ}$. The detector was positioned at $90^{\circ}$ to the beam to collect the X-ray fluorescence emitted from the sediments within the flow-through cell. The input solution, cell, and fraction collector were maintained under anaerobic conditions. 

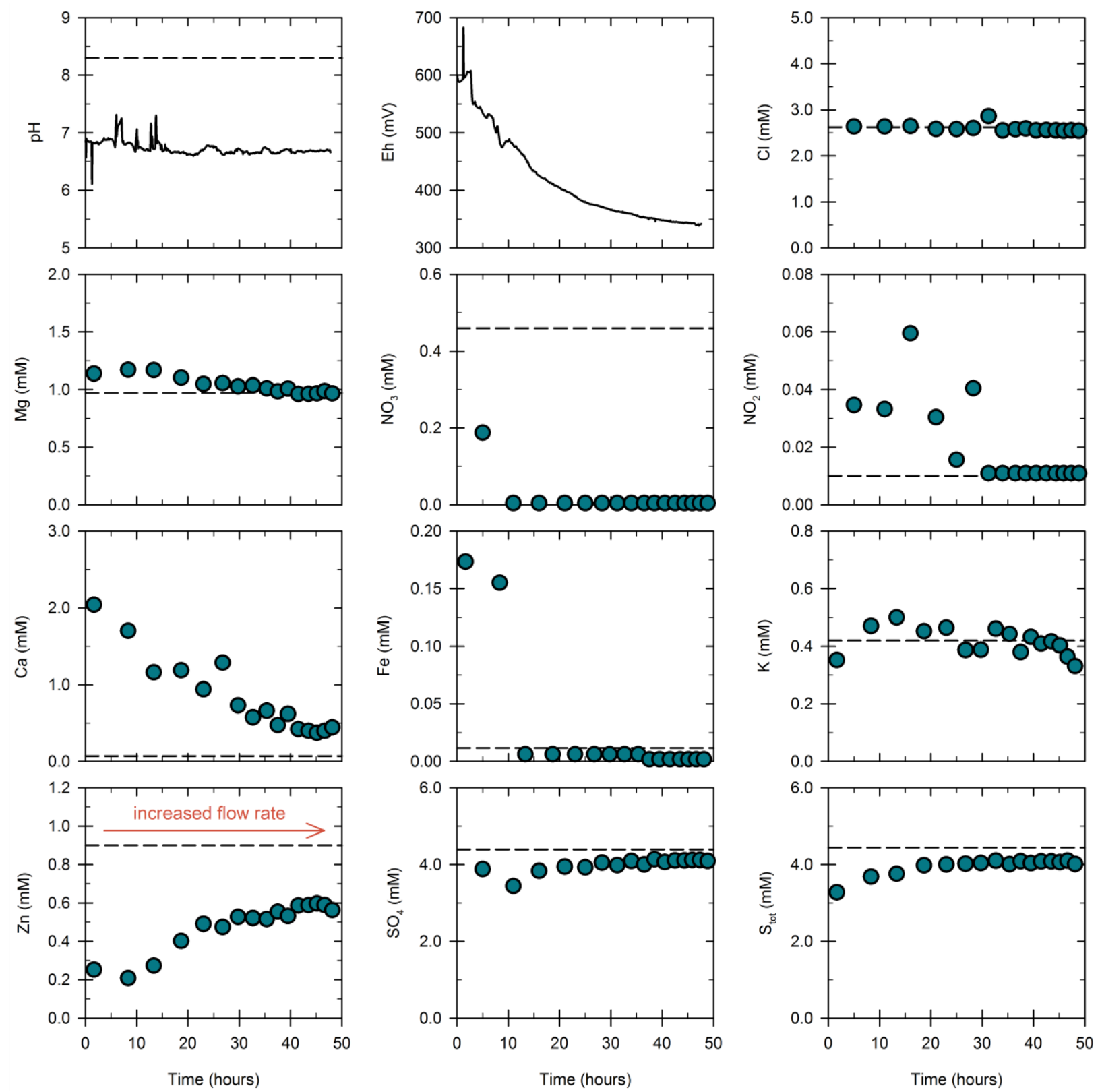

Figure 2. Aqueous geochemical data measured in the effluent over time. Input concentrations and $\mathrm{pH}$ are indicated by dashed lines. The flow rate was increased step-wise over time, starting at $0.8 \mathrm{~mL} \mathrm{~h}^{-1}$ and ending at $4.1 \mathrm{~mL} \mathrm{~h}^{-1}$. 


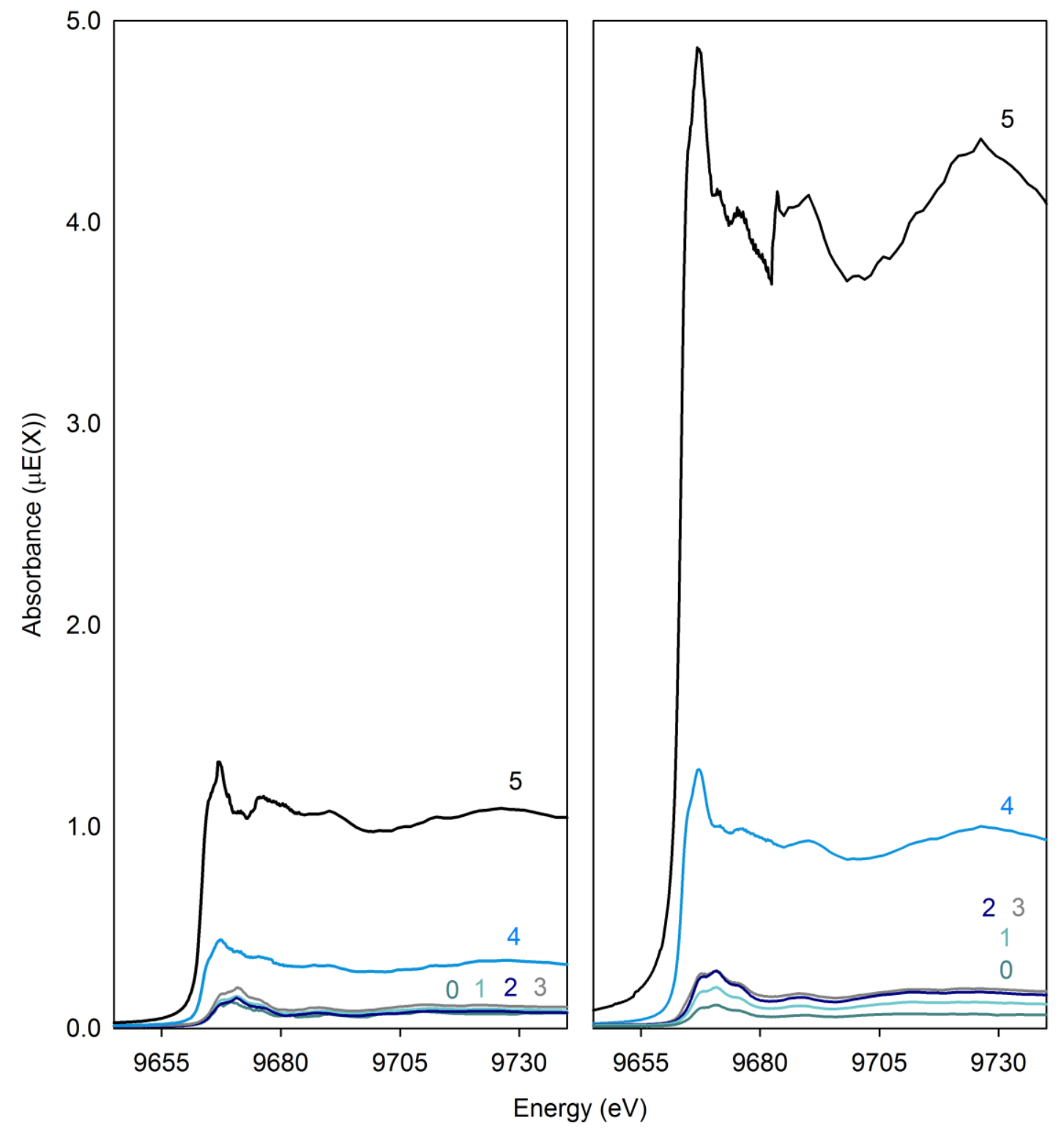

Figure 3. Zinc XANES spectra collected at each of the six positions throughout the FTC, at the beginning of the experiment (left) and at the end of the experiment (right), plotted as $X$ ray absorption vs. energy (i.e., not normalized). Position 0 is closest to the bottom of the cell (input), whereas position 5 is closest to the top (effluent). Positions 4 and 5 showed the greatest accumulation in $\mathrm{Zn}$ mass, as demonstrated by the large increase in $\mathrm{X}$-ray absorption over time. 


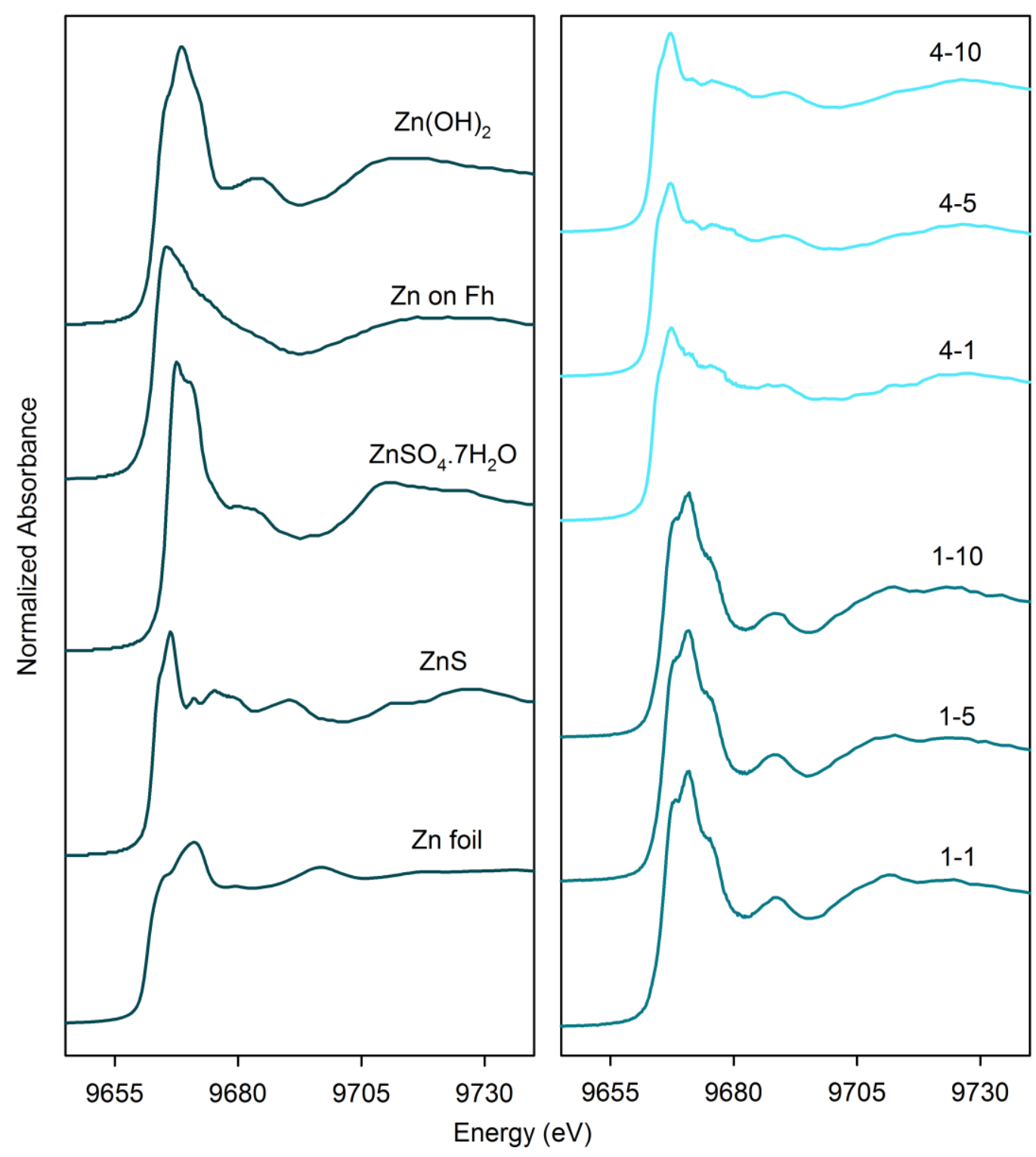

Figure 4. Zinc standards used for linear combination fitting (left) and normalized sample spectra from different cell positions over the course of the experiment (right). Position 1 is near the bottom of the cell, while position 4 is closer to the top. Spectra are presented for timesteps at the beginning (1), middle (5), and end (10) of the experiment. 

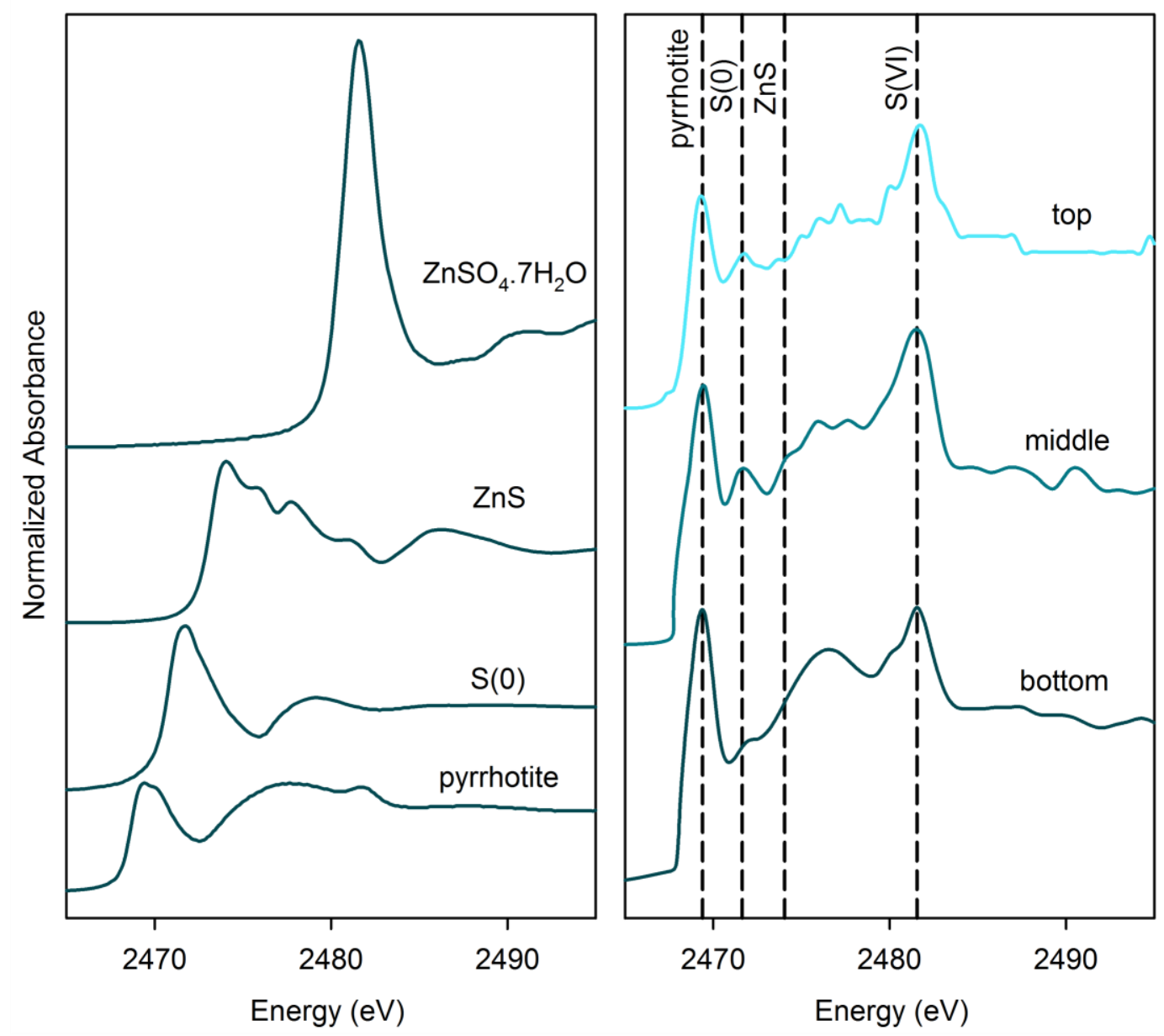

Figure 5. Normalized sulfur XANES collected after the experiment ended on samples (right) from three sections of the solid-phase material (bottom, middle, and top). Sulfur standards used for linear combination fitting are shown on the left. 


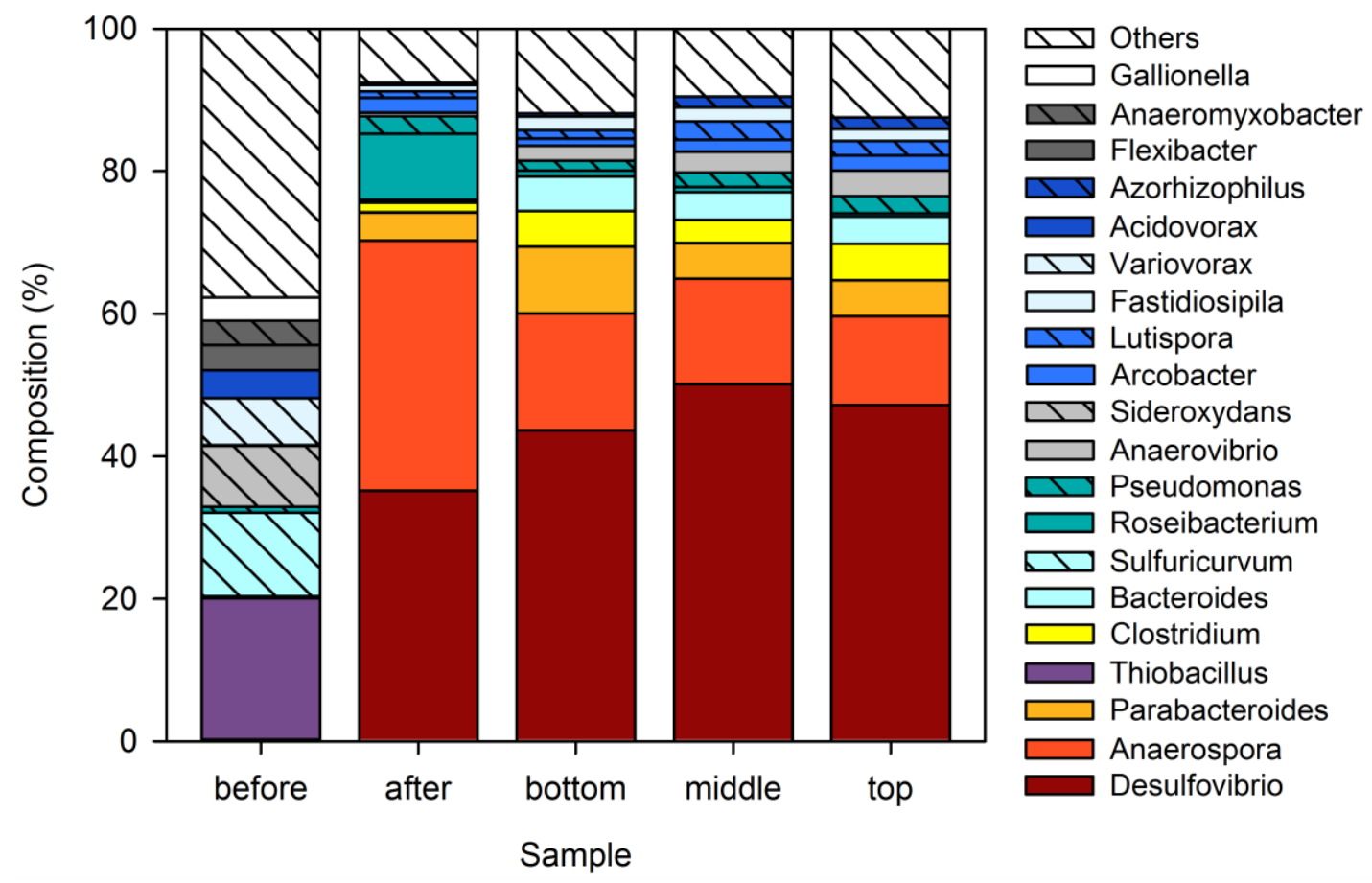

Figure 6. Microbial composition of the sediment, before and after biostimulation, and at three locations along the length of the FTC after the end of the experiment (bottom, middle, and top). Dominance of Desulfovibrio spp. is indicative of anoxic and sulfatereducing conditions. 


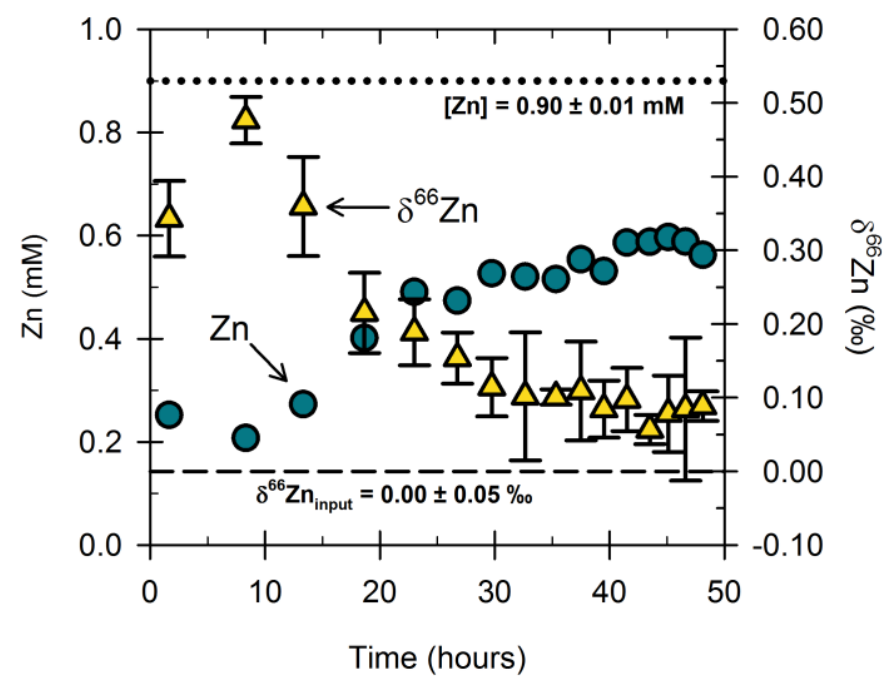

Figure 7. Effluent $\mathrm{Zn}$ concentrations (blue circles) and associated $\delta^{66} \mathrm{Zn}$ values (yellow triangles) plotted over time. All isotope values were normalized to the input solution $\left(\delta^{66} \mathrm{Zn}\right.$ $=0.00 \pm 0.05 \%$ \%). Error bars represent two times the standard deviation on data derived from duplicate sample preparation (for some samples) and triplicate analysis by MC-ICPMS (all samples). Horizontal lines indicate the input solution $\mathrm{Zn}$ concentration (dotted) and $\mathrm{Zn}$ isotope signature (dashed). 


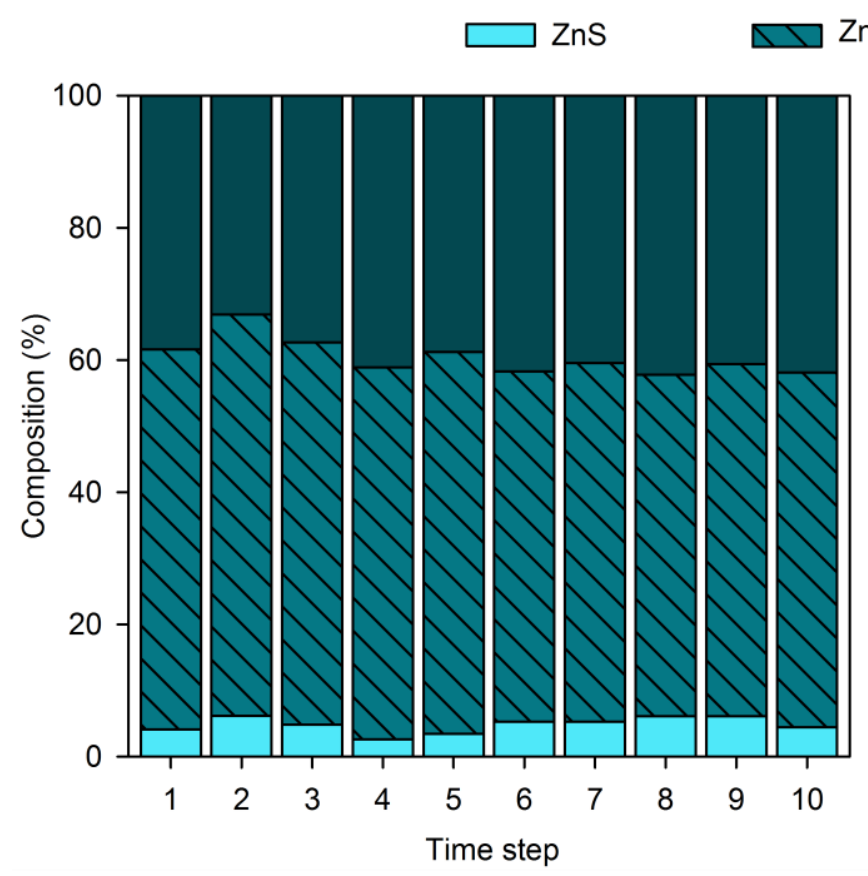

$\mathrm{Zn}(\mathrm{OH})_{2}$

$\mathrm{Zn}$ on $\mathrm{Fh}$

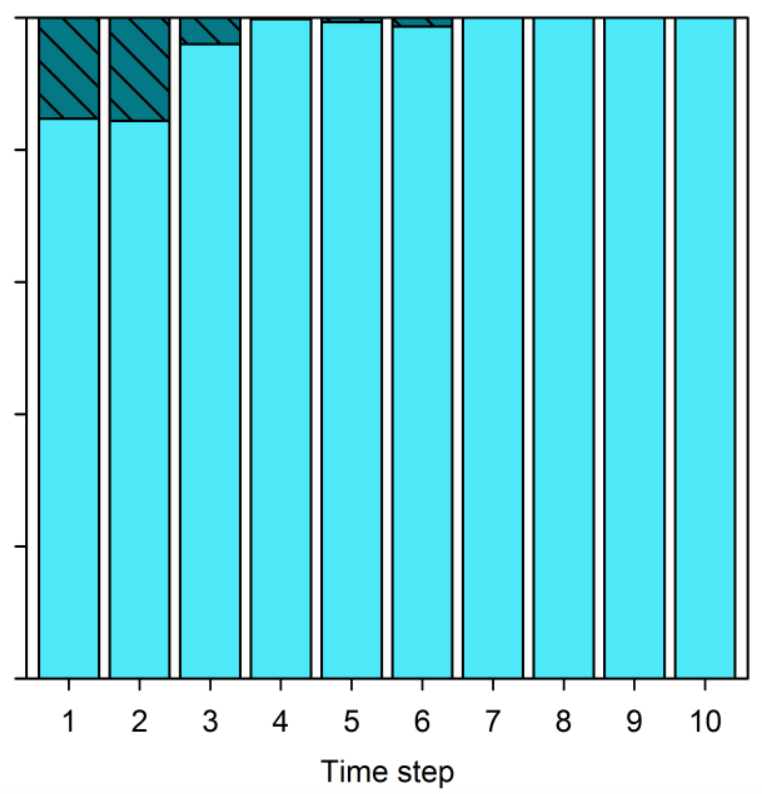

Figure 8. Linear combination fitting results for $\mathrm{Zn}$ K-edge spectra. The left plot depicts position 1 of the cell, while the right plot depicts position 4. Each time step was 50 minutes long, and each position was revisited every five hours. 


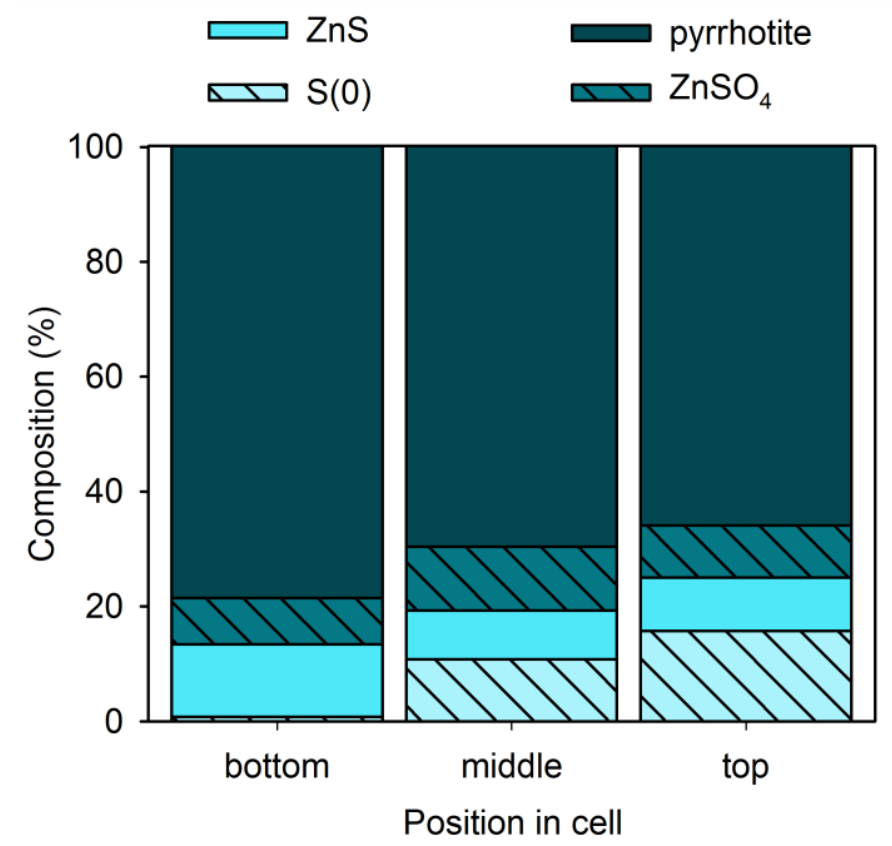

Figure 9. Linear combination fitting results using the derivative for S K-edge XANES. Measurements were performed on subsections of the cell material at the end of the experiment. 


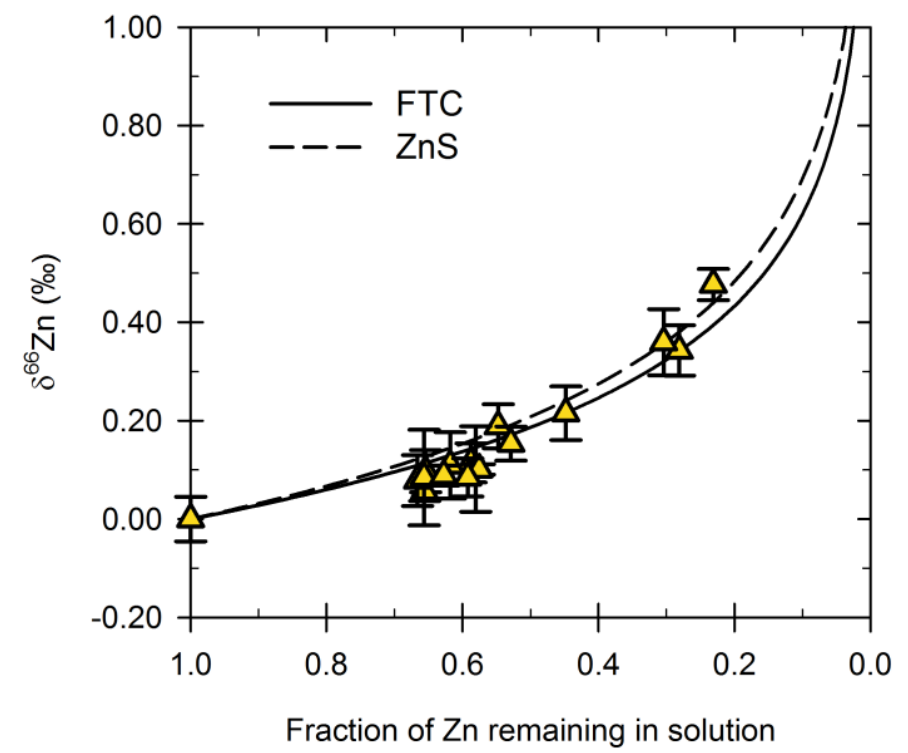

Figure 10. Aqueous isotope results for the flow-through cell plotted as $\delta^{66} \mathrm{Zn}$ vs. the fraction of $\mathrm{Zn}$ remaining in solution. The data was fitted with a Rayleigh curve, resulting in an isotopic fractionation of $\varepsilon=-0.27 \pm 0.06 \%$ (solid line). A curve with the value $\varepsilon=-0.30 \pm$ $0.04 \%$ is plotted to represent the isotopic fractionation determined for $\mathrm{ZnS}$ precipitation by Veeramani et al. (2015) (dashed line). 